\title{
Exploratory Study on Relationship among Body Weight, Body Condition Score and Some Blood Biochemical Parameters of Non-Descriptive Goats in Mzimvubu Local Municipality: A Case of Santombe Village
}

\author{
Siza Mthi ${ }^{*}$, Nkululeko Nyangiwe1,2, Francisca Rumosa Gwaze 3 , Mandla Yawa4, \\ Thobela Louis Tyasi ${ }^{5}$, Sive Tokozwayo', Tanki Thubela', Mlungisi Selby Jansen', \\ Sindisile Goni ${ }^{1}$, Thamsanqa Khetani ${ }^{1}$, Luxolo Qokweni ${ }^{6}$, Soul Washaya ${ }^{7}$, Busiswa Guza ${ }^{8}$, \\ Mlungisi Magwaza ${ }^{8}$, Bekikaya Brilliant Mbangi ${ }^{8}$, Thandile Ndobeni ${ }^{9}$ \\ ${ }^{1}$ Döhne Agricultural Development Institute, Stutterheim, South Africa \\ ${ }^{2}$ Department of Agriculture and Animal Health, University of South Africa, Florida, South Africa \\ ${ }^{3}$ Lovedale TVET College, Alice, South Africa \\ ${ }^{4}$ Department of Livestock and Pasture Science, University of Fort Hare, Alice, South Africa \\ ${ }^{5}$ Department of Agricultural Economics and Animal Production, University of Limpopo, Polokwane, South Africa \\ ${ }^{6}$ Department of Rural Development and Agrarian Reform, Kokstad, South Africa \\ ${ }^{7}$ Department of Livestock, Wildlife \& Fisheries Great Zimbabwe University, Masvingo, Zimbabwe \\ ${ }^{8}$ Department of Rural Development and Agrarian Reform, Mount Ayliff, South Africa \\ ${ }^{9}$ Gauteng Department of Agriculture and Rural Development, Directorate of Primary Animal Health, Johannesburg, South Africa \\ Email: *sizamthie@gmail.com
}

How to cite this paper: Mthi, S., Nyangiwe, N., Gwaze, F.R., Yawa, M., Tyasi, T.L., Tokozwayo, S., Thubela, T., Jansen, M.S., Goni, S., Khetani, T., Qokweni, L., Washaya, S., Guza, B., Magwaza, M., Mbangi, B.B. and Ndobeni, T. (2021) Exploratory Study on Relationship among Body Weight, Body Condition Score and Some Blood Biochemical Parameters of Non-Descriptive Goats in Mzimvubu Local Municipality: A Case of Santombe Village. Open Journal of Animal Sciences, 11, 646-657.

https://doi.org/10.4236/ojas.2021.114044

Received: July 26, 2021

Accepted: October 5, 2021

Published: October 8, 2021

\begin{abstract}
Body weight is a crucial trait that aids farmers in decision-making regarding vaccinations, feeding, marketing and selection during the breeding programs. The study was conducted to investigate the effect of sex and age on body weight (BW), body condition score (BCS) and some blood biochemical parameters (BBP) and to determine the correlation amongst BW, BCS and BBP of non-descriptive goats at Santombe communal farming system. Blood samples were collected from 33 apparently healthy goats (27 females and 6 males) aged 6 - 8 tooth with a mean BW $(32.62 \pm 11.39 \mathrm{~kg})$ while BCS $(3.17 \pm 0.39)$ was taken by means of palpating the lumbar area, sternum and the ribs. The BCS was rated on a scale of 1 to 5 with 1 being emaciated and 5 being extremely fat. The blood samples were analyzed using Cobas intergra 400 plus chemistry analyzer, Roche for biochemical parameters such as total protein (TP), urea, cholesterol (Chol), magnesium $(\mathrm{Mg})$, phosphorous $(\mathrm{P})$ and calcium $(\mathrm{Ca})$
\end{abstract}


Copyright $\odot 2021$ by author(s) and Scientific Research Publishing Inc. This work is licensed under the Creative Commons Attribution International License (CC BY 4.0).

http://creativecommons.org/licenses/by/4.0/ with mean values of $72.79 \pm 5.84 \mathrm{mg} / \mathrm{l}, 2.76 \pm 1.16 \mathrm{mmol} / \mathrm{l}, 2.08 \pm 0.40$ $\mathrm{mmol} / \mathrm{l}, 1.09 \pm 0.09 \mathrm{mmol} / \mathrm{l}, 2.30 \pm 0.49 \mathrm{mmol} / \mathrm{l}$ and $2.45 \pm 0.12 \mathrm{mmol} / \mathrm{l} \mathrm{respec}-$ tively. Sex and age had significant effects on BW, BCS and some biochemical parameters. The BW and BCS for males were significantly higher than for females. Correlation results indicated that BW had a positive relationship with BCS $(r=0.677)$, TP and BW $(r=0.400)$, Chol and BCS $(r=0.4025)$ and $\mathrm{Mg}$ and TP $(r=-0.075)$. Age and sex had significant influences on BW, BCS and some blood biochemical parameters. Consideration of the factors can aid in determining the accurate diagnosis of the nutritional status of goats.

\section{Keywords}

Blood Metabolite, Communal Goats, Nutrition Status

\section{Introduction}

Goats play an important role in the socio-economic and cultural aspects of the rural population [1] [2] [3]. In comparison with other livestock species such as cattle, goats are renowned for their high ability to survive harsh environmental conditions [4] [5] [6] and their lower feed and capital requirements [7] [8] [9]. More so, goat milk fetches higher prices per litre compared to cow milk since the former has nutritionally desirable traits, such as lower concentrations of C12:0, C14:0, C16:0 and Na:K ratios, and higher concentrations of cis-polyunsaturated fatty acids (PUFA) compared to the latter [10]. Regarding meat from the goats, chevon contains less fat, fewer calories and higher levels of protein and iron in comparison with beef, pork, mutton and broiler meat [11] [12].

South Africa has approximately 2 million goats of which $29.6 \%$ are in the Eastern Cape Province [13]. If proper attention is accorded to the farming of this livestock species, goats could become a vehicle for poverty alleviation and wealth creation [14]. Farmers in the communal areas of South Africa can accomplish this objective through devising strategies aimed at efficiently and effectively raising goats. Such strategies should, however, be grounded on the determination of the nutritional status of livestock. Knowledge of the nutritional status of livestock enables owners to neither underfeed their goats resulting in sub-optimal production nor overfeed them culminating in unnecessary costs that then translate into reduced profits. Body weights (BWs), body condition scoring (BCS) and blood metabolite profiling have been used to evaluate the nutritional status of livestock under communal breeding systems [15] [16] [17].

Although some farmers might use body weight as a determinant of nutrient status, the index can be misleading if not properly interpreted. Farmers would be provided with a classification of nutrient level as low, medium and high, and this can be done through a scale of $0-100$ self-explanatory measures. Below 50 to symbolize nutrient deficiency, adequate nutrients between $50-70$, and between 80 - 100 nutrients are said to be highly available. By so doing, farmers are en- 
sured to be better understanding the nutrient indexes. In the case of female animals, it is important to have information on which animals will be pregnant as this physiological status might exaggerate the actual weight of the animal. Even so, the situation is complicated by the possibility of single, twin or triplet fetuses in pregnant animals which might not give the true reflection of the weight of the animal. Another challenge associated with using the BW index is the lack of access to weighing facilities in the communal areas [18]. On the other hand, body condition scoring (BCS) has been reported by various authors as the main indicator of nutritional status. This technique, however, has its disadvantages in that it only assesses subcutaneous fat, and bias between the evaluators may influence the results, as such, it is subjective. It is under such scenarios that blood metabolites become relevant and are strongly recommended. Blood metabolite concentrations constitute an integrated index of the adequacy of nutrient availability in relation to nutrient utilization which involves the physiological state and leads to the known status of nutrients [19] [20] [21]. Knowledge of the metabolite profile is crucial in predicting, diagnosing, and preventing various nutritional, pathological, and metabolic disorders before adverse and irreparable conditions occur [22]. Among other factors, stress, age, sex, genetics, management, type of housing, physiological status and other environmental factors have been reported to have profound effects on BW, BCS and biochemical profiles in small ruminants [20] [23] [24]. It is crucial, therefore, to specify the individual values of metabolic profile and acid-base status for each goat breed. It is documented that there is a breed-specific close relationship between BCS and particular blood metabolites [25]. As for our knowledge, a few studies have been conducted on the use of blood metabolites as an indicator of the nutritional status of goats raised under communal goat breeding systems. This investigation, therefore, was conducted to determine if a relationship exists among BWs, BCS and blood metabolites of non-descript goats reared in Santombe village of the Eastern Cape Province.

\section{Materials and Methods}

\subsection{Description of the Study Site}

The study was conducted in Santombe village that falls under Umzimvubu Local Municipality of the Alfred Nzo district. The village is situated $3 \mathrm{~km}$ North of Mount Ayliff town at $30^{\circ} 49^{\prime} 25^{\prime \prime} \mathrm{S}$ and $27^{\circ} 21^{\prime} 93^{\prime \prime}$. Its elevation is $1330 \mathrm{~m}$ above the sea level and most of the land is gently undulating. The mean annual rainfall is $780 \mathrm{~mm}$ whilst the mean annual temperatures range from $13^{\circ} \mathrm{C}$ to $29^{\circ} \mathrm{C}$. The village covers an area of 719 ha of which a large $(>80 \%)$ area is rangeland. The rangelands at Santombe are shared by members of the community and grazed continuously with no restrictions on stocking rates. The vegetation surrounding Santombe is a mixture of East Griqualand Grassland and Drakensberg Foothill Moist Grassland [26] with a browsing capacity of 1218 goats per annum. The main economic activities in the study area are livestock rearing and sand mining. The estimated livestock population is 1800 , of which $64 \%$ are goats, followed by 
sheep (27\%) and cattle (9\%).

\subsection{Data Collection and Goat Management}

Thirty-three (27 females with kids, 6 males) non-descript 6 and 8 tooth goats were randomly selected from one household (Table 1 ) using a convenient sampling technique. The data was collected on the number of goats available in the household. Variation in a number of females and males might be due to sales of male kids for income as compared to female's weaner or kids. The description by [27] that healthy goats be given BCS of 2.3 to 4.0 was utilized. Therefore, the selected goats were considered clinically healthy animals during data collection as their BCS ranged from 3.0 to 4.0. The goats were kraaled at night and browsed on rangelands from $0800 \mathrm{hrs}$ to $1500 \mathrm{hrs}$ with ad libitum availability of water. The main reason for the goats to be kraaled at $1500 \mathrm{hrs}$ was to enable suckling kids, that remained in the kraal, to have access to their mothers early. Multi-sire breeding system was the dominant practice employed in the village, where bucks were running with does throughout the year. Plastic ear tags were used to monitor and facilitate accurate recording. The main source of feed was grass species and browse plants found in the rangelands. The major vegetation of the area is composed of herbaceous plant species that included Alloteropsis appendiculatus, Aristida congesta, Cynodon dactylon, Cymbopogon plurinodis, Elionorus muticus, Eragrostis chloromelas, Eragrostis curvula, Eragrostis lehmanniana, Eragrostis plana, Heteropogon contortus, Hyperhenia hirta, Paspalam dilatatum and Sporobulus africanus. The predominant woody plants species that goats had at their disposal during the experiment were Aloe ferox, Artemisia afra, Coddia rudis, Diospyrosis lysiodes, Ehretia rigida, Euclea undulata, Grewia occidentalis, Maytenus polycantha, Olea europaea, Rhamnus prinoides, Sersia lucida, Scutia myrtina, Vachellia karoo and Vachellia mearnsii.

Body weights, Body Condition Scores and blood samples were collected once from each of the goats during the spring season, in September 2020 from 0700 hrs to $0900 \mathrm{hrs}$. This was a preliminary investigation as the researchers were instructed by MEC to collect and collate data in that particular household. The body weights were recorded using a digital scale as indicated by [28]. The BCS were scored on a scale of 1 to 5 , with a score of 1 indicating a thin and emaciated goat whilst a condition of 5 indicated an obese goat as explained [29]. The BCS was assigned not only through visual appraisal of an animal but through palpating

Table 1. Age-groups of bucks and does sampled in the study area.

\begin{tabular}{ccccc}
\hline \multirow{2}{*}{ Age (tooth) } & \multicolumn{2}{c}{ Male (Bucks) } & \multicolumn{2}{c}{ Female (Does) } \\
\cline { 2 - 5 } & Number & $\%$ & Number & $\%$ \\
\hline 6 & 3 & 50 & 9 & 67 \\
8 & 3 & 50 & 18 & 100 \\
\hline
\end{tabular}


the lumbar area, sternum and the ribs [30] as well. From each goat, a $10 \mathrm{ml}$ blood sample was collected from the jugular vein into tubes that contained no anticoagulants. The blood samples were transported to the laboratory in an ice pack for analysis of total protein (TP), urea, cholesterol (Chol), calcium (Ca), magnesium $(\mathrm{Mg})$ and phosphorous $(\mathrm{P})$. Total protein was analyzed spectrophotometrically as described by [31]. The Colorimetric method was used to analyze calcium (Ca) [32], phosphorus (P) [33] and magnesium (Mg) [34]. For the analysis of urea and cholesterol (Chol), the [34] enzymatic method was used.

\subsection{Data Analysis}

Data collected was subjected to the Statistical Analysis System version 9.1 [35]. The effects of age and sex on BCS, BW and biochemical parameters (using a serum) were determined using the generalized linear model procedures [35]. Correlation coefficients for BCS, BW and biochemical parameters were determined using PROC CORR procedures [35] Mean separation of the least square means was performed using the PDIFF procedure. Statistical significance was tested at a 95\% level with all results with $\mathrm{P}<0.05$ considered to be statistically significant.

\section{Results}

There were significant differences $(\mathrm{P}<0.001)$ in $\mathrm{BW}$ and $\mathrm{BCS}$ among sex and age groups as shown in Table 2. With reference to each age group, the body weights of males were higher than for females. For BCS, significantly higher scores were observed in the male goats compared with the female counterparts in both age groups (Table 2).

The serum concentration of TP and P were higher than the normal reference values but no significant differences were found either between the two age groups or between the sexes (Table 3). Urea, magnesium and calcium levels were within the reference range for healthy goats under field conditions with neither age nor sex effects on the levels of these metabolites as indicated in Table 3. The results also revealed that cholesterol was significantly lower $(P<0.01)$ in the female 6 tooth goats compared to the other groups.

Correlation coefficients among BW, BCS and blood metabolites are shown in Table 4. Body weight was positively correlated to BCS ( $\mathrm{r}=0.677$; $\mathrm{P}<0.01$ ). There, however, were no correlations $(\mathrm{P}>0.05)$ between $\mathrm{BWs}$ and several blood metabolites such as urea, $\mathrm{Chol}, \mathrm{Mg}, \mathrm{P}$ and $\mathrm{Ca}$. Total protein was only positively correlated with BW ( $r=0.400 ; \mathrm{P}<0.05)$ with no correlation between the TP and other blood parameters and BCS. Urea had no correlation with the other studied blood metabolites, BW and BCS. Cholesterol was positively correlated to BCS ( $\mathrm{r}$ $=0.402 ; \mathrm{P}<0.05)$ and there was no correlation between the blood parameters and BW. As shown in Table 4, BCS were not $(\mathrm{P}>0.05)$ correlated with TP, urea, $\mathrm{Mg}$ and calcium. Amongst the given parameters, magnesium was positively correlated with TP only. No correlation existed between phosphorus and the given parameters. The same observation was also detected regarding calcium. 
Table 2. Effect of age and sex on BW and BCS.

\begin{tabular}{|c|c|c|c|c|}
\hline \multirow{2}{*}{ Parameters } & \multicolumn{2}{|c|}{6 tooth } & \multicolumn{2}{|c|}{8 tooth } \\
\hline & F & M & $\mathrm{F}$ & M \\
\hline BW & $28.14 \pm 1.865^{\mathrm{cd}}$ & $42.07 \pm 3.231^{\mathrm{b}}$ & $32.59 \pm 1.319^{c}$ & $62.33 \pm 3.231^{a}$ \\
\hline BCS & $3.11 \pm 0.090^{\mathrm{b}}$ & $3.67 \pm 0.150^{\mathrm{a}}$ & $3.06 \pm 0.064^{\mathrm{b}}$ & $4.00 \pm 0.157^{\mathrm{a}}$ \\
\hline
\end{tabular}

Values with different superscript within a row differ significantly (P<0.001). Body condition score (BCS); Body weight (BW); Female (F); Male (M).

Table 3. Blood metabolites and macro-mineral profile for non-descript goats of different sex and age groups.

\begin{tabular}{|c|c|c|c|c|c|c|c|}
\hline Age & Sex & $\begin{array}{c}\mathrm{TP} \\
\mathrm{mg} / \mathrm{l}\end{array}$ & $\begin{array}{c}\text { Urea } \\
\mathrm{mmol} / \mathrm{l}\end{array}$ & $\begin{array}{c}\text { Chol } \\
\mathrm{mmol} / \mathrm{l}\end{array}$ & $\begin{array}{c}\mathrm{Mg} \\
\mathrm{mmol} / 1\end{array}$ & $\begin{array}{c}\mathrm{P} \\
\mathrm{mmol} / 1\end{array}$ & $\begin{array}{c}\mathrm{Ca} \\
\mathrm{mmol} / 1\end{array}$ \\
\hline \multirow{2}{*}{6} & $\mathrm{~F}$ & $71.61 \pm 1.806^{\mathrm{ab}}$ & $2.60 \pm 0.400^{\mathrm{a}}$ & $1.94 \pm 0.113^{\mathrm{b}}$ & $1.13 \pm 0.031^{\mathrm{a}}$ & $2.46 \pm 0.16^{\mathrm{a}}$ & $2.49 \pm 0.041^{\mathrm{a}}$ \\
\hline & M & $73.30 \pm 3.830^{\mathrm{ab}}$ & $2.43 \pm 0.693^{\mathrm{a}}$ & $2.63 \pm 0.196^{\mathrm{a}}$ & $1.12 \pm 0.053^{\mathrm{a}}$ & $1.92 \pm 0.280^{\mathrm{ab}}$ & $2.47 \pm 0.070^{\mathrm{a}}$ \\
\hline 8 & $\mathrm{~F}$ & $74.89 \pm 1.314^{\mathrm{a}}$ & $2.92 \pm 0.283^{\mathrm{a}}$ & $2.01 \pm 0.080^{\mathrm{ab}}$ & $1.12 \pm 0.022^{\mathrm{a}}$ & $2.30 \pm 0.114^{\mathrm{a}}$ & $2.42 \pm 0.029^{\mathrm{a}}$ \\
\hline Min-Max & & $61.5-83.9$ & $0.37-4.76$ & $1.42-3.17$ & $0.94-1.28$ & $1.44-3.08$ & $2.21-2.68$ \\
\hline RV & & $64.0-70.0$ & $3.57-7.14$ & $1.10-2.30$ & $0.31-1.48$ & $0.23-0.50$ & $2.23-2.93$ \\
\hline
\end{tabular}

Values with different superscript within a column differ significantly ( $<$ <.001). Reference Values: RV; Minimum: Min; Maximum: Max.

Table 4. Correlation for BW, BCS, blood metabolites and macro-minerals among non-descript goats.

\begin{tabular}{|c|c|c|c|c|c|c|c|}
\hline Variable & BCS & BW & $\mathrm{TP}$ & Urea & Chol & $\mathrm{Mg}$ & $\mathrm{P}$ \\
\hline \multicolumn{8}{|l|}{ BCS } \\
\hline BW & $0.677^{\star \star}$ & & & & & & \\
\hline $\mathrm{TP}$ & $0.308^{\mathrm{NS}}$ & $0.400^{*}$ & & & & & \\
\hline Urea & $0.101^{\mathrm{NS}}$ & $0.074^{\mathrm{NS}}$ & $0.239^{\mathrm{NS}}$ & & & & \\
\hline Chol & $0.402^{*}$ & $0.399^{\mathrm{NS}}$ & $0.235^{\mathrm{NS}}$ & $0.138^{\mathrm{NS}}$ & & & \\
\hline $\mathrm{Mg}$ & $0.268^{\mathrm{NS}}$ & $0.275^{\mathrm{NS}}$ & $0.428^{* *}$ & $-0.075^{\mathrm{NS}}$ & $0.063^{\mathrm{NS}}$ & & \\
\hline $\mathrm{P}$ & $-0.237^{\mathrm{NS}}$ & $-0.119^{\mathrm{NS}}$ & $0.014^{\mathrm{NS}}$ & $-0.285^{\mathrm{NS}}$ & $-0.214^{\mathrm{NS}}$ & $0.022^{\mathrm{NS}}$ & \\
\hline $\mathrm{Ca}$ & $-0.043^{\mathrm{NS}}$ & $-0.193^{\mathrm{NS}}$ & $0.059^{\mathrm{NS}}$ & $0.178^{\mathrm{NS}}$ & $0.000^{\mathrm{NS}}$ & $0.018^{\mathrm{NS}}$ & $0.091^{\mathrm{NS}}$ \\
\hline
\end{tabular}

Significant at ${ }^{* *} \mathrm{P}<0.01 ;{ }^{*} \mathrm{P}<0.05$ and not significant $(\mathrm{NS})$ at $(\mathrm{P}>0.05)$.

\section{Discussion}

The finding, from the current study, that males were heavier than female goats might be attributed to hormonal differences and environmental factors. Similar findings were reported by [36], from research with the indigenous Maefur goats in Ethiopia, where males were found to be heavier than female goats $(42.8 \pm 6.6$ $\mathrm{kg}$ versus $37.2 \pm 4.1 \mathrm{~kg}$ ). [37] also had similar findings from research with the South African indigenous goat where 8 tooth male goats weighed $37.7 \pm 7.17 \mathrm{~kg}$ whilst females of the same age weighed $31.4 \pm 5.87 \mathrm{~kg}$. There are challenges in communal farming set up, one of these is unavailability of weighing scales which assist in marketing live animals as well as selection for breeding purpose [38]. The current study focused on investigation of relationship between BW, BCS 
and biochemical parameters in non-descriptive goats.

Most blood metabolites showed results within the reference values reported by [39]. However, the values of TP, Chol and P were exceptions. The TP, Chol and $\mathrm{P}$ values were observed to be higher than the reference values. High TP levels might be due to dominance of acceptable browse species such as Diospyros and Cordia species which have a crude protein (CP) content above 8\% [40] which is good for feed intake and optimum rumen function in goats. Alternatively, the elevation might be due to breed traits as reported by [41] among other indigenous small ruminants' breeds. Research studies [42] have, however, revealed that total protein (TP) is known to increase due to some adverse scenarios such as dehydration, chronic inflammation and paraproteinaemia, and access to feed containing excess protein. The observed positive correlation between TP and BW might indicate a desirable high level of TP. However, such elevated TP levels warrant investigation so that if they are due to an anomaly then such a condition can be corrected.

The high P concentrations obtained in the current study might be due to the availability of browse plants such as Vachellia karoo which have calcium and phosphorus contents of around $1.73 \%$ and $0.13 \%$, respectively [43]. The high levels might also be attributed to the fact that the experimental goats (30 to 36 months of age) were still growing. [44] reported that the level of $\mathrm{P}$ decreases as the goats grow older since there is reduced capacity to assimilate $\mathrm{P}$ from the diet as the goats grow. Lack of an age effect on $\mathrm{P}$ with reference to goats under the current study could be due to the fact that the two age groups were close to each other.

The findings that urea, magnesium and calcium were within the normal range could probably indicate that the goats had access to browse and forage that had enough of the minerals during the time the blood was sampled. There, however, is a need to investigate if there will not be deficiencies in other seasons. Cholesterol plays an important role as an antioxidant and metabolism of cell-soluble hormones, hormone production, cortisone, bile formation, and fat soluble vitamins. Cholesterol is of clinical importance when present in abnormal concentrations, like many other essential components of the body. Our current finding of the high Chol levels that are above the reference values, usually exhibits abnormalities in the synthesis, degradation and transport of related lipoprotein particles [45]. The high Chol levels, however, might emanate from the absence of excess dietary energy intake which results in the animal mobilizing body fat reserves [46] [47]. The higher cholesterol levels in adult goats compared to values from young female goats can be attributed to the fact that the metabolite is a precursor to all sex steroid hormones and is, therefore, high in concentrations in adult livestock compared to young animals [48].

The significant correlation between BW and BCS indicates that body weight can be predicted based on body condition scores. Similar results were observed by [15] on indigenous Nguni goats of South Africa. This indicates that the combination of BW and BCS would be a good indicator of live weight in goats in 
fields with no access to weighting scale. Contrary to this finding, [49] in Senegalese goats and [50] in indigenous Tswane goats reported a negative correlation between BW and BCS.

Sufficient supply of protein is a very crucial factor for proper growth. The findings from this study shows a positive correlation $(r=0.400$; $\mathrm{P}<0.05)$ between TP and BW. This differs from the findings of [37], who reported that change in protein levels had no effect on Body weight of Badali kids. Cholesterol is an energy source in all living organisms. Body energy reserves, mainly represented by body fat and muscle content, are important determinants of reproductive performance. Based on our results Chol had a positive correlation with body condition score. Similar results were found in previous studies [51]. [52] observed a negative correlation between BCS and Chol on indigenous Nguni goats.

\section{Conclusion}

Non-genetic factors such as sex and age had a significant effect on body weight, body condition and some biochemical parameters of non-descriptive goats. There were strong positive relationships between BW, BCS, total protein, cholesterol and magnesium. Therefore, BW, BCS and some blood metabolites could be good indicators of the nutritional status of goats in Santombe village. Further studies covering all the seasons, with larger sample sizes, are required to give a better understanding of the effect of the studied parameters on the goats studied. Follow-up investigation might include enzyme activities and parameters of the acid-base status to provide more in-depth information so as to explain situations that could not be explained by the current study.

\section{Acknowledgements}

The authors would like to acknowledge the farmers who willingly participated in this study and the Eastern Cape Department of Agriculture Rural Development and Agrarian Reform for providing logistical support.

\section{Conflicts of Interest}

The authors declare no conflicts of interest regarding the publication of this paper.

\section{References}

[1] Rumosa Gwaze, F., Chimonyo, M. and Dzama, K. (2009) Communal Goat Production in Southern Africa: A Review. Tropical Animal Health and Production, 41, 1157-1168. https://doi.org/10.1007/s11250-008-9296-1

[2] Mdladla, K., Dzomba, E. and Muchadeyi, F. (2018) Landscape Genomics and Pathway Analysis to Understand Genetic Adaptation of South African Indigenous Goat Populations. Heredity, 120, 369-378. https://doi.org/10.1038/s41437-017-0044-Z

[3] Monau, P., Raphaja, K., Zvinorova-Chimboza, P. and Gondwe, T. (2020) Sustainable Utilization of Indigenous Goats in Southern Africa: Review. Diversity, 12, 1-9. 
https://doi.org/10.3390/d12010020

[4] Masika, P.J. and Mafu, J.V. (2004) Aspects of Goat Farming in the Communal Farming Systems of the Central Eastern Cape of South Africa. Small Ruminant Research, 52, 161-164. https://doi.org/10.1016/S0921-4488(03)00256-6

[5] Silanikove, N. (2010) The Physiological Basis of Adaptation in Goats to Harsh Environments. Small Ruminant Research, 35, 181-193. https://doi.org/10.1016/S0921-4488(99)00096-6

[6] Ncube, K.T., Hadebe, K., Dzomba, E.F. Soma, P., Frylinck, L. and Muchadeyi, F.C. (2020) Relationship between Population Genomic Structure and Growth Profiles of South African Goats under Different Production Systems. Tropical Animal Health and Production, 52, 1277-1286. https://doi.org/10.1007/s11250-019-02128-1

[7] Girma, D., Misgana, D. and Feyisa, H. (2011) Effect of Different Factors on Mortality Rate of Arsi-Bale Kids in Mid Rift Valley of Ethiopia. Global Veterinaria, 6, 56-60.

[8] Gilo, B.N. and Berta, T.S. (2016) Assessment of Livestock Feed Resources and Feeding Systems in Haramaya District, Eastern Ethiopia. International Journal of Livestock Production, 7, 106-112. https://doi.org/10.5897/IJLP2016.0321

[9] Monteiro, A., Costa, J.M. and Lima, M.J. (2017) Goat System Production: Advantages and Disadvantages to the Animal, Environment and Farmer. https://doi.org/10.5772/intechopen.70002

[10] Pietrzak-Fiecko, R. and Kamelska-Sadowska, A.M. (2020) The Comparison of Nutritional Value of Human Milk with Other Mammals' Milk. Nutrients, 12, 1-18.

https://doi.org/10.3390/nu12051404

[11] Department of Agriculture Forestry and Fisheries (DAFF) (2013) A Profile of the South African Goat Market Value Chain. Directorate Marketing, Pretoria.

[12] Mazhangara, I.R., Chivandi, E., Mupangwa, J.F. and Muchenje, V. (2019) The Potential of Goat Meat in the Red Meat Industry: Review. Sustainability, 11, 1-12. https://doi.org/10.3390/su11133671

[13] Statistics South Africa (StatsSA) (2016) October Household Survey (OHS). Government Printer, Pretoria.

[14] Ng'ambi, J., Alabi, J. and Dannah, N. (2013) Role of Goats in Food Security, Poverty Alleviation and Prosperity with Special Reference to Sub-Saharan Africa: A Review. Indian Journal of Animal Research, 47, 1-9.

[15] Rumosa Gwaze, F., Chimonyo, M. and Dzama, K. (2010) Nutritionally-Related Blood Metabolites and Faecal Egg Counts in Indigenous Nguni Goats of South Africa. South African Journal of Animal Science, 40, 480-484.

[16] Radin, L., Vugrovečki, A.S., Hlede, J.P., Vince, S., Ljubičič, I. and Šimpraga, M. (2017) Blood Metabolites of Extensively Reared Croatian Multi-Coloured Goats during Lactation and Early Gravidity. Veterinarski Arhiv, 87, 273-280. https://doi.org/10.24099/vet.arhiv.151223

[17] Washaya, S., Mupangwa, J. and Muchenje, V. (2018) Chemical Composition of Lablab purpureus and Vigna unguiculata and Their Subsequent Effects on Methane Production in Xhosa Lop-Eared Goats. South African Journal of Animal Science, 48, 445-458. https://doi.org/10.4314/sajas.v48i3.5

[18] Mahmud, M.A., Shaba, P. and Zubairu, U.Y. (2020) Live Body Weight Estimation in Small Ruminants-A Review. Global Journal of Animal Scientific Research, 2, 102-108.

[19] Mohammed, S.A., Razzaque, M.A., Omar, A.E., Albert, S. and Al-Gallaf, W.M. 
(2016) Biochemical and Haematological Profile of Different Breeds of Goat Maintained under Intensive Production System. African Journal of Biotechnology, 15, 1253-1257. https://doi.org/10.5897/AJB2016.15362

[20] Antunovic, Z., Speranda, M., Jnovosele, C., Didara, M., Mioč, B., Klir, Z. and Samac, D. (2017) Blood Metabolic Profile and Acid-Base Balance of Dairy Goats and Their Kids during Lactation. Veterinarski Arhiv, 87, 43-55.

[21] Redlberger, S., Fisher, S.H., Kohler, R., Diller, B. and Reinhold, P. (2017) AgeDependent Physiological Dynamics in Acid-Base Balance, Electrolytes, and Blood Metabolites in Growing Goats. The Veterinary Journal, 229, 45-52. https://doi.org/10.1016/j.tvjl.2017.10.017

[22] Elitok, B. (2012) Reference Values for Haematological and Biochemical Parameters in Saanen Goats Breeding in Afyonkarahisar Province. Kocatepe Veterinary Journal, 5, 7-11.

[23] Ribeiro, M.N., Ribeiro, N.L., Bozzi, R. and Costa, R.G. (2018) Physiological and Biochemical Blood Variables of Goats Subjected to Heat Stress-A Review. Journal of Applied Animal Research, 46, 1036-1041. https://doi.org/10.1080/09712119.2018.1456439

[24] Gartner, T., Zoche-Golob, V., Redlberger, S., Reinhold, P. and Donat, K. (2019) Acid-Base Assessment of Post-Parturient German Holstein Dairy Cows from Jugular Venous Blood and Urine: A Comparison of the Strong Ion Approach and Traditional Blood Gas Analysis. PLoS ONE, 14, e0210948.

https://doi.org/10.1371/journal.pone.0210948

[25] Qureshi, H.U., Qureshi, M.S., Khan, R., Rahman, A., Sohail, S.M., Ijaz, A., Ahmad, I., Ahamad, S., Shoaib, M. and Basit, A. (2016) Relationship of Blood Metabolites with Reproductive Cyclicity in Dairy Cows. Indian Journal of Animal Research, 50, 338-348. https://doi.org/10.18805/ijar.10713

[26] Mucina, L. and Rutherford, M.C. (2011) The Vegetation of South Africa, Lesotho and Swaziland. Strelitzia 19. South African Biodiversity Institute, Pretoria.

[27] Yilmaz, M., Taskin, T., Bardakcioglu, H.E. and Di-loria, A. (2014) Effect of Body Condition Score on Some Blood Parameters for Anaemia Level Goats. Veterinarija Ir Zootechnika (Veterinary Medicine and Zootechnics), 67, 41-46.

[28] Tyasi, T.L., Mathye, N.D., Danguru, L.W., Rashijane, L.T., Mokoena, K., Makgowo, K.M., Mathapo, M.C., Molabe, K.M., Bopape, P.M. and Maluleke, D. (2020) Correlation and Path Analysis of Body Weight and Biometric Traits of Nguni Cattle Breed. Journal of Advanced Veterinary and Animal Research, 7, 148-155. https://doi.org/10.5455/javar.2020.g404

[29] Kenyon, P.R., Maloney, S.K. and Blache, D. (2014) Review of Sheep Body Condition Score in Relation to Production Characteristics. New Zealand Journal of Agricultural Research, 57, 38-64. https://doi.org/10.1080/00288233.2013.857698

[30] Ghosh, C.P., Datta, S., Mandal, D., Das, A.K. and Roy, A.N.K. (2019) Body Condition Scoring in Goat: Impact and Significance. Journal of Entomology and Zoology Studies, 7, 554-560.

[31] Weichselbaum, T.E. (1946) An Accurate and Rapid Method for 12 the Determination of Proteins in Small Amounts of Blood Serum and Plasma. American Journal of Clinical Pathology, 16, 40-49. https://doi.org/10.1093/ajcp/16.3_ts.40

[32] Cali, J.P., Bowers, G.N. and Young, D.S. (1973) A Reference Method for the Determination of Total Calcium in Serum. Clinical Chemistry, 19, 1208-1213. https://doi.org/10.1093/clinchem/19.10.1208 
[33] Young, D.S. (1990) Effects of Drugs on Clinical Laboratory Tests. 3rd Edition, AACC Press, Washington DC.

[34] Tietz, N. (1976) Fundamentals of Clinical Chemistry. W.B. Saunders, Philadelphia.

[35] Gotchman, N. and Schmitc. J.M. (1972) Application of a New Peroxidase Indicator Reaction to the Specific, Automated Determination of Glucose with Glucose Oxidase. Clinical Chemistry, 18, 943. https://doi.org/10.1093/clinchem/18.9.943

[36] SAS (Statistical Analysis System) (2003) Statistical Analysis System Institute Inc. Users Guide, Version 9, Carry, NC, USA.

[37] Gebreyowhens, W. and Kumar, R. (2017) Phenotypic Characterization of Indigenous Maefur Goat Population in Tigray, Northern Ethiopia. International Journal of Biodiversity and Conservation, 9, 130-145. https://doi.org/10.5897/IJBC2016.1057

[38] Simela, L., Webb, E.C. and Bosman M.J.C. (2011) Live Animal and Carcass Characteristics of South African Indigenous Goats. South African Journal of Animal Science, 41, 1-15. https://doi.org/10.4314/sajas.v41i1.66032

[39] Abdelrahman, M.M. and Aljumaah, R.S. (2014) Dietary Protein Level and Performance of Growing Baladi Kids. Iranian Journal of Veterinary Research, 15, 353-358.

[40] Kaneko, J.J. (1997) Serum Proteins and the Dysproteinemias. In: Kaneko, J.J., Harvey, J.W. and Bruss, M.L., Eds., Clinical Biochemistry of Domestic Animals, 5th Edition, Academic Press, San Diego, 117-138.

https://doi.org/10.1016/B978-012396305-5/50006-3

[41] Mthi, S., Rust, J.M. and Morgenthal, T.L. (2016) Partial Nutritional Evaluation of Some Browser Plant Species Utilized by Communal Livestock in the Eastern Cape Province, South Africa. Applied Animal Husbandry \& Rural Development, 9, 25-30.

[42] Simpraga, M., Smuc, T., Matanovic, K., Radin, L., Shek-Vugrovecki, A., Ljubicic, I. and Vojta, A. (2013) Reference Intervals for Organically Raised Sheep: Effects of Breed, Location and Season on Haematological and Biochemical Parameters. Small Ruminant Research, 112, 1-6. https://doi.org/10.1016/j.smallrumres.2012.11.032

[43] Rumosa Gwaze, F., Chimonyo, M. and Dzama, K. (2010) Relationship between Nutritionally-Related Blood Metabolites and Gastrointestinal Parasites in Nguni Goats of South Africa. Asian-Australasian Journal of Animal Sciences, 23, 1190-1197. https://doi.org/10.5713/ajas.2010.90547

[44] Kiran, S., Bhutta, A.M., Khan, B.A., Durrani, S., Ali, M., Ali, M. and Iqbal, F. (2012) Effect of Age and Gender on Some Blood Biochemical Parameters of Apparently Health Small Ruminants from Southern Punjab in Pakistan. Asian Pacific Journal of Tropical Biomedicine, 2, 304-306. https://doi.org/10.1016/S2221-1691(12)60028-8

[45] Mapiye, C., Chimonyo, M., Dzama, K., Marufu, M.C., Strydom, P.E. and Muchenje, V. (2009) Nutritional Status Growth Performance and Carcass Characteristics of Nguni Steers Supplemented with Acacia Karroo Leaf-Meal. Livestock Science, 126, 206-214. https://doi.org/10.1016/j.livsci.2009.07.001

[46] Mbassa, G.K. and Poulsen, J.S.D. (1991) Influence of Pregnancy, Lactation and Environment on Some Clinical Chemical Reference Values in Danish Landrace Dairy Goats (Capra hircus) of Different Parity-II. Plasma Urea, Creatinine, Bilirubin, Cholesterol, Glucose and Total Serum Proteins. Comparative Biochemistry and Physiology, 100B, 423-431. https://doi.org/10.1016/0305-0491(91)90396-U

[47] Cox, R.A. and García-Palmieri, M.R. (1990) Cholesterol, Triglycerides, and Associated Lipoproteins. In: Walker, H.K., Hall, W.D. and Hurst, J.W., Eds., Clinical Methods. The History, Physical, and Laboratory Examinations, 3rd Edition, Butterworths, Boston. 
[48] Ingraham, R.H. and Kappel, L.C. (1988) Metabolic Profile Testing. Veterinary Clinics of North America: Food Animal Practice, 4, 391-411.

https://doi.org/10.1016/S0749-0720(15)31056-2

[49] Ruegg, P.L., Goodger, W.J., Holmberg, C.A., Weaver, L.D. and Huffman, E.M. (1992) Relation among Body Condition Score, Milk Production, and Serum Urea Nitrogen and Cholesterol Concentrations in High-Producing Holstein Dairy Cows in Early Lactation. American Journal of Veterinary Research, 53, 5-9.

[50] Saez, F., Ouvrier, A., et al. (2011) Epididymis Cholesterol Homeostasis and Sperm Fertilizing Ability. Asian Journal of Andrology, 13, 11-17.

https://doi.org/10.1038/aja.2010.64

[51] Cissé, M., M’Baye, M., Sane, I., Corréa, A. and N’Diaye, I. (2002) Seasonal Changes in Body Condition of the Senegalese Sahel Goat: Relationship to Reproductive Performance. Ministry of Agriculture, Senegal.

https://agris.fao.org/agris-search/search.do?recordID=QM9500032

[52] Nsoso, S.J., Aganga, A.A., Moganetsi, B.P. and Tshwenyane, S.O. (2003) Body Weight, Body Condition Score and Heart Girth in Indigenous Tswana Goats during the Dry and Wet Seasons in Southeast Botswana. Livestock Research for Rural Development, 15, 4-11. http://www.lrrd.org/lrrd15/4/nsos154.htm 